\title{
Anna Bernard, Rhetorics of Belonging: Nation, Narration, and Israel/Palestine
}

\section{Claire Gallien}

\section{(2) OpenEdition \\ 1 Journals}

Electronic version

URL: https://journals.openedition.org/ces/5693

DOI: $10.4000 /$ ces.5693

ISSN: 2534-6695

Publisher

SEPC (Société d'études des pays du Commonwealth)

\section{Printed version}

Date of publication: 1 April 2015

Number of pages: 109-111

ISSN: 2270-0633

\section{Electronic reference}

Claire Gallien, "Anna Bernard, Rhetorics of Belonging: Nation, Narration, and Israel/Palestine",

Commonwealth Essays and Studies [Online], 37.2 | 2015, Online since 13 April 2021, connection on 17 July 2021. URL: http://journals.openedition.org/ces/5693 ; DOI: https://doi.org/10.4000/ces.5693

This text was automatically generated on 17 July 2021.

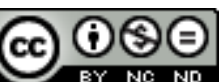

Commonwealth Essays and Studies is licensed under a Licence Creative Commons Attribution - Pas d'Utilisation Commerciale - Pas de Modification 4.0 International. 


\title{
Anna Bernard, Rhetorics of Belonging: Nation, Narration, and Israel/Palestine
}

\author{
Claire Gallien
}

\section{REFERENCES}

Anna Bernard. Rhetorics of Belonging: Nation, Narration, and Israel/Palestine. Liverpool: Liverpool UP, 2013. 205 p. ISBN (hb): 978-1-84631-943-3. £75.00

1 In the very first lines of Rhetorics of Belonging: Nation, Narration, and Israel/Palestine, Anna Bernard offers a summary of the scope of her publication: "This is a book about the cultural representation, transmission, and circulation of the Israeli-Palestinian conflict. It examines the ways in which Palestinian and Israeli writers whose work achieves the status of 'world literature' [...] intervene in the asymmetrically waged local and international contests over the region's political past and future." (1) Bernard's book also has a crucial theoretical dimension since it engages with various fields, namely postcolonial studies, comparative literature, and translation studies, which have come under duress of late.

2 Rhetorics of Belonging addresses the Jamesonian concept of "national allegory" considered by many contemporary critics as a thing of the past or as too clichéd. It also takes on the field of postcolonial studies - declared "dead" by Negri and Hardt in Empire - and promotes a literature which has, for political, institutional, and linguistic reasons, been largely side-lined by postcolonial scholars, despite the colonial genealogy and nature of the Israeli state and despite the common depiction of the Palestinian as the "abject" figure of oppression. ${ }^{1}$

3 Furthermore, it brings together national narratives (grounding the analysis in a discussion of Jameson and Anderson) and postcolonialism (engaging with Said, Ahmad, Lazarus, Chakrabarty, Brennan, and Parry, among others), when the two appear to be based on opposite if not incompatible premises; namely a homogeneous and autotelic vision of the nation on the one hand (national narratives are supposed to be 
homogeneous, simplistic and binary) and processes of hybridisation and transnationalism on the other (postcolonial novels are supposed to be complex, multilingual, meta-reflexive, and parodic).

4 The way the author achieves this subversion is not only by focusing on the "materialist," as opposed to the "idealist," branch of postcolonial studies, but also by reinvesting the very definition of national allegories as sutured visions of the nation. Palestinian and Israeli literatures of the nation are naming a problem, not a solution, i.e., how to "respond to the sense of permanent and specifically national crisis" (24). Finally, the book offers a relational analysis of Israeli and Palestinian literary forms and imaginaries, caught as they are in a settler-native relation, while remaining careful not to confuse relationality with reconciliation.

5 Except for chapter 1, which is a substantial theoretical addition to the introduction and provides a defence and reclamation of the Jamesonian concept of "national allegory," each subsequent chapter of Rhetorics of Belonging presents fascinating and detailed analyses of the works of specific Israeli and Palestinian writers, namely Edward Said, Mourid Bhargouti, Amos Oz, Orly Castel-Bloom, Sahar Khalifeh, and Anton Shammas. While Israeli and Palestinian narratives are revisited through the postcolonial lens, postcolonialism is reconsidered, and its limitations and potential complicity with globalisation and neo-imperialism fully addressed, via robust literary analysis of the primary texts.

6 Thus, Bernard argues that dismissing national allegories as a thing of the past is tantamount to imposing a Western post-national cultural map on the rest of the globe and to being complicit with an imposed transnational global order. Furthermore, she concurs that the absence of Palestinian/Israeli texts within postcolonial literature is "troubling" given the status of Israel as a settler-colonial state (20). Another problematic illustration of the symbiotic relationship between criticism and geopolitics is the currency gained in academic discourse by the "two-narrative" paradigm, which clearly takes its cue from the "two-state" solution, emphasising "the intractability of all nationalist politics for a cosmopolitan audience encouraged to congratulate itself on its own putative post-nationalism" (32).

7 This statement is fundamental because it later allows Bernard to develop her concept of the "demographic imaginary" as a corrective to Anderson's "social imaginary" in order to address the specificity of the Israel/Palestine situation where no national consensus has been reached. Bernard's "demographic imaginary" accounts for the prominence of the border - both external, between Israel and Palestine, and internal, with second-class (Mizrahi, Ethiopian) and third-class (Palestinian) citizens in Israel and for the importance of questions related to citizenship, political rights and ethnicity.

8 Chapters 2 and 3 deal with Palestinian autobiographical narratives, namely Edward Said's Out of Place and Mourid Barghouti's I Saw Ramallah, which constitute two opposite ways of defining Palestinian demographic imagination, the first relying on exile, and the second on grounded sensory experiences. Chapter 4 turns to Amos Oz's fictions and traces ideological affiliations with Zionism in them when his narrators invoke the Nakba but then undermine its power to disturb the readers. Similarly, Oz's parodic use of racist Orientalist clichés against Arabs implies their non-relevance to the current Israeli context, thus effectively removing any sort of affiliation between Zionism, Orientalism and colonialism. 
Chapter 5 revisits the national allegory paradigm from an intersectional and marginalised perspective and details the ways in which female writers, namely Sahar Khalifeh and Orly Castel-Bloom, criticize the gender-nationalism nexus present in Israeli and Palestinian societies. Israeli land grab is couched as a masculine onslaught on historic Palestine, while misogyny and patriarchy subjugate women's bodies and minds and reveal a darker side to Israel's alleged modern and progressive state. Chapter 6 on Anton Shammas's Arabesques offers, along with the chapters on Barghouti and $\mathrm{Oz}$, one of Bernard's most inspiring analyses, one in which the narration of the nation envisions a post-Zionist state - that is to say post-ethnic and post-nationalist.

Given that Bernard clearly indicates the scope of her corpus, her book does not claim to exhaust the topic of Israeli/Palestinian national narrations, but rather invites further enquiries, most notably concerning questions of reception and form. How are the works studied and received in Israel/Palestine? Would an inclusion of other genres, such as refugee, prison, or infiltration narratives, provide new insights into the topic discussed and highlight the disparity and fundamental imbalance between the two situations?

11 This being said, Anna Bernard's book is both a challenging and a highly stimulating read for scholars working on Israeli and Palestinian literatures and more generally for those working in postcolonial, comparative, and translation studies. It combines intellectual and stylistic clarity with insightful close readings, theoretical rethinking, and an attention to the politics of form. Her command of both English and Arabic enables her to attend to the multifarious facets of literariness and to the ways in which texts, as "worldly" aesthetic artefacts, may engage readers, actuate change, and rearticulate ideologies.

\section{NOTES}

1. See Rebecca L. Stein, "Ballad of the Sad Café: Israeli Leisure, Palestinian Terror, and the Post/ colonial Question," Postcolonial Studies and Beyond, ed. Ania Loomba et al. Durham, NC: Duke UP, 2005.

\section{AUTHORS}

\section{CLAIRE GALLIEN}

Claire GALLIEN lectures in the English Department at Paul Valéry University in Montpellier and is a member of IRCL (UMR 5186). Her research interests are anchored in the critical study of orientalist discourse, in postcolonial, comparative, and world literatures and theories, as well as 
in translation studies. Her first book, L'Orient anglais (Voltaire Foundation, 2011), deals with the interactions between popular and scholarly cultures of the East in $18^{\text {th }}$-century England. Her current book project, From Corpus to Canon, focuses on the construction of the category of "Eastern literature" (Arab, Persian, and Indian) in England in the early modern period and its entanglements with structures of European knowledge and power. 